\title{
Nonword Reading Tests: A Review of the Available Resources - Corrigendum
}

Danielle Colenbrander, Lyndsey Nickels and Saskia Kohnen

doi: http://dx.doi.org/10.1375/ajse.35.2.137, Published by Australian Academic Press

On page 137 the author affiliations should be as follows:

Danielle Colenbrander ${ }^{1,2}$, Lyndsey Nickels ${ }^{1}$ and Saskia Kohnen ${ }^{1,2}$

${ }^{1} A R C$ Centre of Excellence in Cognition and its Disorders (CCD), Macquarie University, Sydney, Australia

${ }^{2}$ MULTILIT Research Unit, Sydney, Australia

\section{Reference}

Danielle Colenbrander, Lyndsey Nickels and Saskia Kohnen, Nonword Reading Tests: A Review of the Available Resources. Australasian Journal of Special Education, 35(2), 137-172, http://dx.doi.org/10.1375/ajse.35.2.137 